\title{
The geopolitics of book publishing and book reviews
}

\author{
K. Brad Wray ${ }^{1} \cdot$ Lori Nash $^{1} \cdot$ Jonathan Simon ${ }^{2}$ \\ Accepted: 4 October 2021 / Published online: 15 October 2021 \\ (c) The Author(s), under exclusive licence to Springer Nature B.V. 2021
}

As editors of Metascience, we spend a lot of time trying to get books from publishers to reviewers. Indeed, as our managing editor, this is one of Lori's principle responsibilities. As you can imagine, getting books to reviewer is an essential step in publishing a review on a newly published book. If this part of the process is interrupted or disturbed, then we have many unhappy book authors, publishers, reviewers, and readers. This is a surprisingly complex process, subject to the influence of many contingencies that might seem far removed from academic publishing and research.

With the spread of Covid-19, we have vividly seen the forces at work in the geopolitics of book publishing and book reviewing. During this time, many academics were unable to get to their offices. So, not surprisingly, they requested that the books be sent to their home addresses. What better way to spend an indefinitely long lockdown than to read a colleague's book and write a review. But this was not such a simple solution. A large number of our colleagues had to learn how to teach on-line in record time and were often burdened with supplementary responsibilities because of the epidemic. The staff who work for the various book publishers were also obviously affected by the lockdown, and many were unable to go to their usual places of work, making processing book orders more challenging. I do not claim to know the details of the challenges they faced, but many tasks became more complicated. Add to this mix that both the academics who agreed to write reviews for us, and the people working for the publishers processing the book orders away from their offices, often had children to take care of, children who were no longer at school during the day. It is a miracle that anything got done.

\footnotetext{
K. Brad Wray

kbwray@css.au.dk

Lori Nash

lorinash@css.au.dk

Jonathan Simon

jonathan.simon@univ-lorraine.fr

1 Centre for Science Studies, Aarhus University, Aarhus, Denmark

2 Philosophy Department, Université de Lorraine, Nancy, France
} 
During the lockdown, another great geo-political event occurred, specifically, Brexit. We at Metascience are hardly the foremost victims of Brexit, but it has proved a great challenge, raising new obstacles for book publishers, especially academic book publishers. Oxford University Press and Cambridge University Press, for example, publish a lot of high-profile books in philosophy of science, and we often carry reviews of books from these publishers. Prospective book authors are honored, and rightly so, to publish with these presses and reviewers are also often quite keen to review them. But shipping books out of the UK has proved to be a challenge this past year and a half, with a considerable slowing down of processing and delivery at the beginning. We also wondered during the early stages of Brexit whether there would be extra costs associated with getting books from the UK to European Union countries. Books were not moving as fast as we were used to, and worrying about this effect has already cost us a certain amount of time. But most things have now fallen into place, and academic books seem to be moving freely across the English Channel again, with only the familiar pre-Brexit difficulties to contend with. This being said, there still seem to be problems with getting books from the UK to Switzerland. At one point, it looked like reviewers receiving books in Switzerland might be obliged to pay a duty in order to receive their books. While this issue is not yet fully resolved, we are certainly not prepared to ask our reviewers to pay to review a book for our journal!

While you might have thought that running a journal that only publishes book reviews was a simple task, Metascience is not immune to the effects of global geopolitics. We hope that the current issue of the journal does not bear any traces of the stress and strains that recent changes in the geopolitics of book publishing and book reviews have brought on us. Despite Brexit and the Covid pandemic, the November issue has come out, and we would like to thank all the book authors and our reviewers, as well as the publishers, their staff, and the people responsible for delivering the books from the places they were printed to the places where they were read and appreciated.

Publisher's Note Springer Nature remains neutral with regard to jurisdictional claims in published maps and institutional affiliations. 